\title{
Teknik Pembibitan Tanaman Kelor (Moringa oleifera Lam) dalam Rangka Penyediaan Sumber Pangan Sehat Berkelanjutan di Desa Gumantar Lombok Utara
}

\author{
Bambang Budi Santoso ${ }^{1)}$, I Nyoman Soemeinaboedhy S.), Jayaputra' \\ ${ }^{1)}$ Kelompok Peneliti Bidang Ilmu Pengembangan Pertanian Lahan Kering, \\ Fakultas Pertanian Unram. \\ 2) Kelompok Peneliti Bidang Ilmu Konservasi Lahan, Fakultas Pertanian Unram
}

\begin{abstract}
Article history
Received: 15 Oktober 2020

Revised: 25 Oktober 2020

Accepted: 11 November 2020

*Corresponding Author:

Bambang Budi Santoso
\end{abstract}

Kelompok Peneliti Bidang Ilmu Pengembangan Pertanian Lahan Kering,

Fakultas Pertanian, Universitas Mataram,

Mataram, NTB,

Indonesai;

Email:

bambang.bs@unram.ac.id.

\begin{abstract}
In the context of realizing, maintaining and improving the highest public health status, community service activities was carried out in the form of extension activities. The target object of community service activities in the form of counseling on Moringa oleifera Lam seedling nursery techniques in the context of providing healthy food sources in Gumantar Village, North Lombok Gumantar Village, Kayangan District, North Lombok Regency, especially members of the Telaga Valley Farmers Group, and the Hamlet Amor-Amor apparatus. The activity that carried out was one of the services to the community, namely the delivery of information through teaching and discussions as well as demonstrations of Moringa plant nursery techniques. To see whether farmers are responsive to the material that was presented, on this occasion it was observed from the feedback or response to questions asked by farmers during the discussion after the material was delivered and also the level of enthusiasm of the participants in practicing the method of Moringa plant nursery. The results shows that there was an increase in the understanding and knowledge of the members of the Valley of Telaga farmer groups regarding the benefits of the Moringa plant as a source of healthy food and a versatile plant. Increased knowledge on plant nursery techniques to produce good quality moringa seedlings, and resulted in vegetative and generative brochures for moringa plant nurseries.
\end{abstract}

Keywords: cultivation; generative; intensive; health; food; vegetative

Abtrak: Dalam rangka mewujudkan, mempertahankan, dan meningkatkan derajat kesehatan masyarakat yang setinggi-tingginya, maka telah dilakukan kegiatan pengabdian masyarakat berupa kegiatan penyuluhan. Obyek sasaran kegiatan pengabdian pada masyarakat berupa penyuluhan Teknik Pembibitan Tanaman Kelor (Moringa oleifera Lam) dalam Rangka Penyediaan Sumber Pangan Sehat dan Bahan Bakar Minyak Alternatif Ramah Lingkungan di Desa Gumantar, Lombok Utara adalah masyarakat yang ada di Desa Gumantar, Kecamatan Kayangan, Kabupaten Lombok Utara, khususnya anggota Kelompok Tani Lembah Telaga, dan aparat Dusun AmorAmor. Kegiatan yang telah dilaksanakan merupakan salah satu pelayanan kepada masyarakat, yaitu berupa penyampaian informasi melalui ceramah dan diskusi serta demontrasi teknik pembibitan tanaman kelor. Untuk melihat tanggap tidaknya petani terhadap materi yang telah disampaikan, pada kesempatan ini diamati dari umpan balik atau respon pertanyaan yang diajukan oleh petani pada saat diskusi setelah materi disampaikan dan juga tingkat antusiasme peserta ikut mempraktekan cara pembibitan tanaman kelor. Hasil kegiatan menunjukkan bahwa terjadi peningkatan pemahaman dan pengetahuan anggota kelompok tani Lembah Telaga terhadap manfaat tanaman 
kelor sebagai sumber pangan sehat dan tanaman yang serba guna. Peningkatan pengetahuan pada teknik pembibitan tanaman untuk menghasilkan bibit kelor berkualitas baik, dan dihasilkan brosur pembibitan tanaman kelor secara vegetatif dan secara generatif.

Kata kunci: budidaya; generative; intensif; kesehatan; pangan; vegetatif

\section{PENDAHULUAN}

Kesehatan merupakan hak asasi manusia dan salah satu unsur kesejahteraan yang harus diwujudkan sesuai dengan cita-cita bangsa Indonesia sebagaimana dimaksud dalam Pancasila dan UUD 1945. Namun demikian, mewujudkan, mempertahankan, dan meningkatkan derajat kesehatan masyarakat yang setinggi-tingginya, merupakan kewajiban setiap warga Negara, dituangkan dan diamanatkan dalam Undang-Undang Nomor 36 tahun 2009.

Selain daripada itu, pertumbuhan konsumsi yang sangat cepat terhadap minyak dan pasokan bahan bakar minyak bumi yang tidak dapat diperbaharui dan jumlahnya semakin berkurang menyebabkan kesulitan dalam perekonomian Indonesia dan menyebabkan fenomena yang tidak menentu terkait krisis bahan bakar minyak (BBM). Sebagai alternatif pemecahannya pemerintah berusaha mencari sumber-sumber bahan bakar alternatif yang mungkin untuk dikembangkan. Biodiesel yang merupakan bahan bakar nabati (BBN) adalah salah satu sumber bahan bakar alternatif yang dikembangkan (Siregar et al., 2005; Kadiman, 2006) karena bersifat ramah lingkungan dan dapat diperbaharui dibandingkan dengan solar atau petroleum diesel (Daryanto, 2005; Manurung, 2006), serta pengembangannya akan berdampak luas terhadap aspek ekonomi masyarakat (Saad, 2006).

Salah satu tanaman sumber pangan sehat dan berhasiat obat (kesehatan) sekaligus sumber alternatif bahan bakar minyak adalah tanaman Kelor (Moringa oleifera Lam). Oleh karena itu, kami selaku peneliti pengembang tanaman kelor menetapkan untuk mengambil bagian dalam implementasi amanah Undang-Undang tersebut, yaitu turut serta membantu mewujudkan, mempertahankan dan meningkatkan derajat kesehatan masyarakat yang setinggi-tingginya, melalui pemanfaatan tanaman Kelor sebagai asupan nutrisi tinggi bagi masyarakat.

Bahwa Moringa oleifera Lam yang kita kenal dengan nama Kelor adalah salah satu tanaman yang bergizi, sejak dahulu dikenal oleh masyarakat sebagai tanaman yang berkhasiat. Menurut Haryadi (2011), daun Kelor kering per $100 \mathrm{~g}$ mengandung air 7,5\%, kalori $205 \mathrm{~g}$, karbohidrat 38,2 g, protein 27,1 g, lemak 2,3 g, serat 19,2 g, kalsium $2003 \mathrm{mg}$, magnesium $368 \mathrm{mg}$, fosfor $204 \mathrm{mg}$, tembaga 0,6 mg, besi 28,2 mg, sulfur $870 \mathrm{mg}$, potasium $1324 \mathrm{mg}$. Jadi, tanaman kelor (Moringa oleifera) merupakan salah satu tanaman ajaib sumber pangan dan pengobatan, serta sumber energi alternatif bahan bakar yang ramah lingkungan. Tanaman kelor menjadi pilihan yang layak karena tanaman kelor dapat hidup di lahan kritis. Sehubungan dengan semakin mahalnya harga minyak dunia, tanaman ini dapat menjadi pengganti sumber minyak. Oleh karena itu, budidaya tanaman ini diharapkan mampu menyediakan sumber bahan bakar alternatif atau substitusi, dapat meningkatkan taraf hidup dan tambahan penghasilan masyarakat (khususnya petani), dapat menanggulangi 
kemiskinan dan penambahan hasil devisa, serta memperbaiki lingkungan, dan sekaligus penyangga sumber pangan dan obat.

Penanaman tanaman kelor sementara ini terutama sebagai tanaman pagar. Pemanfaatan buah dan dan batang tanaman kelor di Indonesia (dan juga beberapa daerah) belum optimal. Agar dapat memanfaatkan tanaman kelor sebagai sumber pangan sehat dan sekaligus obat, serta alternatif bahan bakar minyak, maka mengenal tanaman ini lebih dekat dan sekaligus mempersiapkan teknologi budidayanya perlu menjadi perhatian. Sampai saat ini secara umum teknik budidaya tanaman kelor belum diketahui karena kurangnya perhatian terhadap tanaman ini, demikian pula halnya dengan aspek pembibitan maupun pertumbuhan dan perkembangan tanaman yang tergolong tahunan (perennial).

Sebagai awal kegiatan budidaya tanaman kelor tentunya penyediaan benih atau bibit perlu mendapat perhatian agar supaya hasil pertanaman di lapang produksi memberikan hasil yang memuaskan. Sasaran utama pembibitan adalah menyediakan bahan tanaman (bibit) yang bermutu baik dengan biaya yang wajar, sehingga dapat mendukung program penanaman yang tepat di lapangan. Kegiatan pembibitan juga akan menentukan kualitas, kuantitas, sebaran waktu, dan volume kegiatan pada tahapan proses kegiatan penanaman dan pasca penanaman di lapangan. Sementara itu, tujuan pembibitan adalah untuk memperoleh bahan tanaman yang pertumbuhannya baik, seragam, dan untuk mempersiapkan bahan tanam untuk penyulaman. Bila bibit tanaman yang ditanam di lapangan merupakan bibit yang telah terseleksi maka diharapkan pertumbuhan dan perkembangan tanaman pada masa vegetatif dan generatif akan lebih baik.

Persemaian merupakan tempat atau areal untuk kegiatan memproses benih atau bagian tanaman lain menjadi bibit siap ditanam kelapangan, dalam jumlah yang memadai, ukuran yang relatif seragam, kualitas yang memadai dan dalam waktu yang tepat. Selain untuk memproduksi bibit, persemaian juga dapat difungsikan untuk aklimatisasi (penyesuaian kondisi lingkungan) dengan kondisi lapangan dimana bibit tersebut akan ditanam.

Kegiatan pengabdian pada masyarakat yang berupa kegiatan sosialisasi dan demplot terkait manfaat dan pembibitan tanaman kelor ini bertujuan: membuka wawasan masyarakat (Kelompok Tani Lembah Telaga Desa Gumantar, Kabupaten Lombok Utara) tentang manfaat tanaman kelor sebagai sumber pangan sehat dan meningkatkan pemahaman dan pengetahuan masyarakat pada pentingnya mempersiapkan bibit tanaman kelor sebagai salah satu tahapan dalam proses produksi tanaman yang dibudidayakan secara intensif. Manfaat dari kegiatan pengabdian pada masyarakat inipun diharapkan: masyarakat (kelompok tani) dapat mengetahui manfaat tanaman kelor sebagai tanaman sumber pangan sehat dan alternatif bahan bakar minyak, dan juga manfaat lainnya dan kemudian terjadi peningkatan pengetahuan pada teknik pembibitan tanaman kelor untuk menghasilkan bibit yang berkualitas.

\section{METODE PELAKSANAAN KEGIATAN}

Obyek sasaran kegiatan pengabdian pada masyarakat berupa penyuluhan atau Sosialisasi Tanaman Kelor sebagai Sumber Pangan Sehat dan Bahan Bakar Minyak Alternatif Ramah Lingkungan, dan teknik pembibitan tanaman adalah masyarakat yang ada di Desa Gumantar, 
Kecamatan Kayangan, Kabupaten Lombok Utara, khususnya anggota kelompok tani Lembah Telaga yang terdiri atas wanita tani sekaligus ibu rumah tangga, remaja, petani (ketua kelompok tani dan anggotanya), dan juga ketua Dusun.

Sesuai dengan target luaran, maka akan dilakukan pengumpulan data dengan menggunakan metode observasi. Sedangkan untuk menyusun program aksi dilakukan melalui kegiatan pertemuan sumbang saran (partisipatif) yang difasilitasi oleh Tim guna menghasilkan agenda aksi yang lebih mencerminkan kebutuhan kelompok sasaran dan ketersediaan sumberdaya setempat dalam upaya optimalisasi pemanfaatan pekarangan (lahan). Dengan menggunakan pendekatan partisipatif program aksi yang dihasilkan merupakan program aksi yang dibutuhkan oleh masyarakat. Oleh karena itu, dalam kegiatan ini masyarakat dilibatkan dalam kegiatan perencanaan dan pelaksanaan program. Dengan cara seperti ini, maka diharapkan bahwa program aksi yang tersusun nanti adalah program yang sesuai dengan kebutuhan masyarakat.

Kegiatan Penyuluhan dilaksanakan dengan cara ceramah disertai dengan presentasi menggunakan Power Point dan dikuti diskusi/ tanya jawab. Ceramah dan diskusi dilakukan untuk memberikan pemahaman tentang arti pentingnya tanaman kelor sebagai sumber pangan sehat dan sekaligus sumber alternatif bahan bakar minyak yang ramah lingkungan, dan juga teknik-teknik pembibitan tanaman. Presentasi Power Point dimaksudkan untuk mempertegas maksud dari ceramah dan memberikan contoh-contoh pemanfaatan tanaman kelor sebagai sumber pangan, obat (kesehatan), dan energi, serta teknik pembibitan yang baik. Teknik pembibitan dimasud adalah teknik pembibitan secaea generative dengan menggunakan biji dan teknik pembibitan secara vegetative dengan menggunakan stek batang. Selain dilakukan ceramah dan diskusi, serta tayangan Power Point, kepada peserta penyuluhan diberikan leaflet perihal tanaman kelor terutama teknik pembibitan tanaman, serta bersama-sama melakukan demplot pembibitan.

Untuk melihat tanggap tidaknya petani terhadap materi yang telah disampaikan, dapat diamati dari umpan balik/respon pertanyaan yang diajukan oleh petani pada saat diskusi setelah materi disampaikan. Selain itu juga dievaluasi dengan cara mengamati individu petani selama melaksanakan praktek pembibitan di saat demplot pembibitan dilakukan.

\section{HASIL KEGIATAN DAN PEMBAHASAN}

\section{A. Pelaksanaan Kegiatan}

Realisasi Pelaksanaan Kegiatan Pengenalan Teknik Pembibitan Tanaman Kelor (Moringa oleifera Lam) di kelompok tanai Lembah Telaga, dusun Amor-Amor, Desa Gumantar, Kecamatan Kayangan, Kabupaten Lombok Utara telah dilaksanakan selama 6 bulan. Kegiatan meliputi survei kondisi kelompok tani, diskusi kebutuhan, pembuatan dan pengajuan proposal, dan pelaksanaan pengabdian kepada masyarakat berupa pengenalan teknik pembibitan tanaman kelor, yang disertai dengan kegiatan praktek bersama prihal pembibitan dimaksud.

Pada saat penyuluhan yang merupakan kegiatan terakhir dihadiri pula oleh berepa orang mahasiswa Sekolah Tinggi Pertanian Malang. Mahasiswa-mahasiswa ini mengikuti kegiatan Dinas Pertanian Tanaman Pangan Hortikultura dan Perkebunan Nusa Tenggara Barat. Selain itu dihadiri 
sebagian besar anggota kelompok tani Lembah Telaga dan kepala dusun, Kaur Pembangunan Desa Gumantar serta Penyuluh Pertanian Lapangan (PPL).

Kegiatan praktik pembibitan melalui pengabdian ini adalah semacam demontrasi plot hanya sebagai contoh bagaimana teknik pembibitan tanaman kelor yang baik, belum dapat mengatasi kebutuhan bibit seluruh warga, karena untuk dapat memenuhi kebutuhan bibit warga dibutuhkan sistem pembibitan yang cukup intensif dan luas. Dengan adanya bimbingan oleh tim pengabdian ini, anggota kelompok tani diharapkan bisa membuat tempat atau areal pembibitan secara mandiri untuk memenuhi kebutuhannya sendiri ataupun untuk keperluan masyarakat di sekitarnya.

Pada kegiatan pengabdian ini langkah yang dilakukan menggunakan pendekatan kualitatif, sehingga hasil kegiatan akan dapat diuraikan dan dianalisis sesuai dengan kondisi atau keadaan yang terjadi di lapangan. Teknik pendekatan awal adalah data yang digunakan antara lain: 1) Observasi langsung, 2) Wawancara, 3) Pembuatan dan mengajuan Proposal, dan 4) Pelaksanaan Kegiatan.

Berdasarkan hasil studi awal diketahui bahwa sebagian besar masyarakat memerlukan pengetahuan dan teknologi budidaya tanaman kelor. Hal ini dikarenakan dalam satu tahun terakhirnya ini, banyak konsumen memerlukan dan membutuhkan produk dari tanaman kelor, terutama biomassa daun dan juga biji kelor. Untuk itu, masyarakat sebagian besar memenuhi keperluan tersebut dengan cara memanen tanaman kelor yang telah lama tumbuh dan berkembang. Dapat dikatakan dengan kata ekplorasi terhadap tanaman yang telah ada tanpa pemeliharaan selanjutnya. Akibat daripada itu sebagian besar tanaman kelor yang ada terlihat dan mengalami kerusakan.

Dengan adanya kegiatan pengabdian kepada masyarakat ini maka usaha perbaikan teknik bercocok tanam tanaman kelor nantinya dapat terlaksana sehingga keberlanjutan produksi tanaman kelor ada diperoleh secara optimal. Oleh karena itu perlu sentuhan pendekatan sosial, ilmu pengetahuan dan teknologi budidaya tanaman kelor dalam bentuk penerapan teknologi tepat guna sehingga hasilnya dapat dibuktikan oleh masyarakat. Dengan adanya kegiatan pengabdian kepada masyarakat ini dapat memberikan manfaat pada masyarakat dalam bentuk perbaikan pengetahuan akan manfaat tanaman kelor dan teknologi budidaya tanaman untuk peroleh hasil baik berupa sumber pangan sehat maupun sebagai sumber alternatif bahan bakar minyak sehingga paling tidak kesehatan masyarakat meningkat, dan juga kesejahteraan ekonomi-sosial masyarakat tercapai.

Realisasi pelaksanaan kegiatan pengabdian kepada msyarakat di lapangan adalah sebagai berikut: Studi awal ke Amor-Amor, Desa Gumantar untuk melihat persoalan yang ada dan yang perlu diatasi segera, kemudian pembuatan proposal. Pada tahap ini telah dilakukan identifikasi dan perumusan masalah. Kemudian tahap berikutnya adalah pengajuan proposal. Setelah proposal diterima kemudian dilakukan kegiatan di lapangan. Adapun kegiatan yang telah dilakukan sebagai berikut,

Kegiatan pertama, berlangsung sesuai rencana, dilakukan identifikasi ulang secara singkat terhadap masalah untuk menentukan jenis penerapan teknologi yang sesuai untuk budidaya tanaman kelor. Pada identifikasi masalah ini diperoleh informasi bahwa penyebab diperlukannya teknik budidaya tanaman kelor adalah karena kebutuhan produk hasil tanaman kelor semakin diminati sementara itu tanaman sumber penghasilan merupakan tanaman yang telah tumbuh dan berkembang sejak lama 
(25-30 tahun lalu) yang tumbuh dan berkembang begitu saja tanpa pemeliharaan. Sehingga teknologi tepat guna yang perlu diberikan adalah teknik penyiapan bibit tanaman (teknologi pembibitan tanaman kelor).

Kegiatan kedua, sosialisasi kegiatan kepada seluruh anggota kelompok tani Lembah Telaga, untuk sekaligus menyampaikan materi teknik pembibitan tanaman kelor. Adapun teknik pembibitan yang disampaikan kepada anggota kelompok tani berupa teknik pembibitan secara vegetatif dengan menggunakan stek batang, dan teknik pembibitan secara generatif dengan menggunakan biji. Kegiatan juga diarahkan untuk mempersiapkan pelaksanaan kegiatan praktek atau demonstrasi pembibitan.

Kegiatan ketiga, demonstrasi teknologi tepat guna untuk penyediaan atau pengadaan bibit tanaman kelor. Demo ini sekaligus untuk mengajak masyarakat (anggota kelompok tani Lembah Telaga) untuk dapat atau mampu membuat bibit tanaman kelor sendiri dan pemeliharaannya secara mandiri. Beberapa masalah dalam mempersiapkan bahan tanaman kelor (jika mereka ingin menanam) adalah dengan memotong batang kelor sepanjang minimal satu meter dan kemudian dibiarkan beridi tegak di tempat teduh. Setelah terlihat tunas tumbuh dan akar-akar yang terlihat berjumlah terbatas, baru kemudian potongan batang tersebut ditanam di tempat (lokasi) yang dikehendaki. Belum ada sentuhan untuk usaha perbaikan dalam penyediaan bibit yang efisien dan efektif. Hal ini menghasilkan bahan tanaman (bibit) yang tidak berkualitas dan terbatas dalam jumlah. Untuk memperbaiki teknologi penyiapan bahan tanaman (bibit) bermutu.

Kegiatan keempat, merupakan kegiatan penutup dari kegiatan pengabdian kepada masyarakat ini, yaitu berupa kegiatan ceramah (penyuluhan) terkait teknik pembibitan dan terkait dengan apa yang telah dilakukan oleh para anggota kelompok tani selama mempraktekkan pembibitan tanaman kelor. Pada kegiatan ini disampaikan materi (berupa leaflet) teknik pembibitan. Adapun sebagian besar materi yang tertuang dalam leaflet tersebut adalah langkah kerja yang telah dilakukan oleh mereka sendiri dan juga diperkaya dengan materi-materi hasil penelitian anggota tim penyuluh beserta mahasiswa Faklultas Pertanian melalui penelitian untuk penulisan skripsi mereka. Diperlukan adanya penerapan teknologi tepat guna.

Selama berlangsung kegiatan keempat tersebut, antusias anggota kelompok tani dan peserta penyuluhan lainnya sangat tinggi. Hal tersebut terlihat dari cukup banyaknya pertanyaan yang diajukan dan juga harapan-harapan segera tumbuh dan berkembang tanaman kelor di pinggir jalan desa atau paling tidak di halaman depan rumah mereka sebagai pagar pembatas.

\section{B. Pembahasan}

Teknologi bercocok tanam atau berkebun kelor dan perawatannya yang mudah membuat banyak orang mengembangkan tanaman ini. Karena manfaat kelor yang cukup besar untuk kesehatan, banyak obat-obat herbal menggunakan bahan baku atau ekstrak daun kelor ini menjadikan permintaan akan kelor ini pun semakin hari semakin meningkat. Hal ini menjadi peluang usaha untuk membudidayakan tanaman kelor. 
Bibit merupakan bahan awal pertanaman bagi tanaman tahunan seperti kelor. Sebagai bahan awal pertanaman maka bibit sangat memegang peranan penting bagi suksesnya bertanam tanaman kelor.

Pemahaman hal tersebut di atas oleh para anggota kelompok tani Lembah Telaga pasca kegiatan pengabdian kepada masyarakat ini telah meningkat. Meningkatkan pemahaman dan pengetahuan masyarakat bahwa tanaman kelor bermanfaat sebagai sumber pangan sehat dan tanaman yang serba guna termasuk pemanfaatannya sebagai sumber alternatif bahan bakar minyak. Tidak itu saja, anggota kelompok tani Lembah Telaga juga meningkat pengetahuannya pada pemanfaatan lahan pekarangan, kebun dan tegalan dengan memanfaatkan tanaman kelor, sehingga nantinya masyarakat dapat menjadikan tanaman kelor sebagai komoditi dalam mencapai kemandirian pangan dan kemandirian energi.

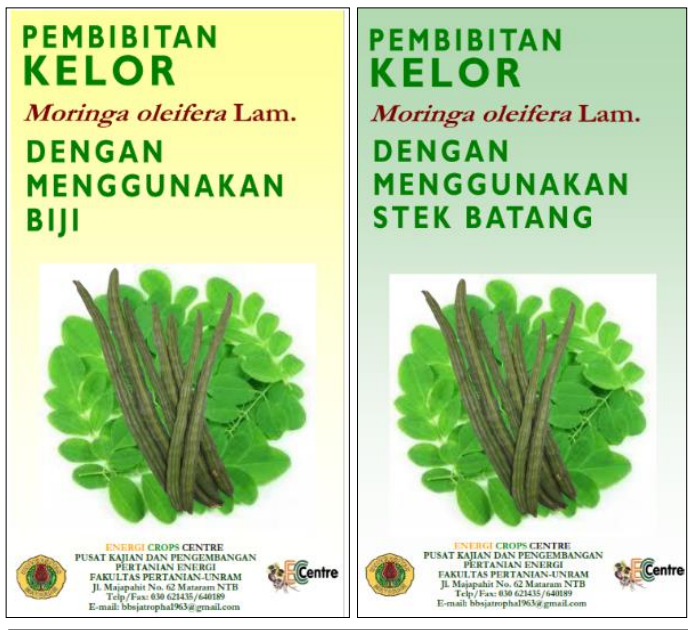

Gambar 1. Leaflet teknik pembibitan tanaman kelor yang diperoleh dari kegiatan pengabdian pada masyarakat ini.
Sehubungan dengan persiapan awal dalam merealisasikan ketertarikan mereka terhadap tanaman kelor, anggota kelompok tani Lembah Telaga juga telah meningkatkan pengetahuan pada teknik pembibitan tanaman untuk menghasilkan bibit kelor berkualitas baik. Hal ini dapat dilihat dengan keaktifan mereka dalam mempraktekkan cara pembibitan tanaman kelor ini. Bahkan yang awalnya dipersiapkan masing-masing satu bibit untuk satu orang, mereka sebagian besar ingin melakukan lebih. Melalui kegiatan ini dihasilkan petunjuk pembibitan tanaman kelor secara vegetative (menggunakan stek batang) dan petunjuk pembibitan tanaman kelor secara generative (menggunakan biji) dalam bentuk leaflet (brosur).

Melalui kegiatan ini, para anggota kelompok tani Lembah Telaga memahami bahwa, perbanyakan dengan biji mempunyai persyaratan yang berbeda dengan perbanyakan dengan stek batang. Tanaman yang diperbanyak dengan biji mempunyai pertumbuhan yang sangat lamban pada awal karena pertumbuhan lebih kepada pengembangan akar sehingga tanaman sangat rentan terhadap persaingan dengan gulma sehingga tanaman perlu disiang dengan teratur, namun setelah akar bertumbuh dengan baik tanaman menjadi lebih kokoh, tumbuh dengan cepat, tahan kekeringan dan mampu mengasilkan biomas daun yang tinggi. Oleh karena itu perlu dilakukan beberapa tindakan untuk dapat mempercepat pertumbuhan Kelor yang ditanam dengan biji.

Bibit tanaman yang berasal dari stek batang biasanya dapat tumbuh lebih cepet dibandingkan yang berasal dari biji, hanya saja sistem perakarannya kurang kuat karena tidak mempunyai akar tunggang hal itu menyebabkan tanaman menjadi rawan terhadap kelembapan dan lebih mudah roboh bila diterpa angin kencang. Membuat stek batang dapat digunakan cabang yang sudah agak tua, sekurang-kurangnya sudah berumur satu tahun dengan diameter 2-6 cm, panjang 50-75 cm. Batang 
stek diaklimatisasi terlebih dahulu selama 3 hari baru kemudian ditanam dalam pot atau kantong plastik yang telah diisi media tanam. Setelah tumbuh tunas-tunasnya baru kemudian dipindahkan ke kebun.

\section{KESIMPULAN}

Peningkatan pemahaman dan pengetahuan anggota Kelompok Tani Lembah Telaga terhadap manfaat tanaman kelor sebagai sumber pangan sehat dan tanaman yang serba guna. Selain itu, peningkatan juga terjadi pada pengetahuan pada pemanfaatan lahan pekarangan, kebun dan tegalan dengan memanfaatkan tanaman kelor, sehingga nantinya masyarakat dapat menjadikan tanaman kelor sebagai komoditi dalam mencapai kemandirian pangan dan kemandirian energi. Hal yang paling penting adalah bahwa pada beberapa anggota Kelompok Tani Lembah Telaga secara nyata meningkat pengetahuannya dalam hal teknik pembibitan tanaman untuk menghasilkan bibit kelor berkualitas baik, baik melalui teknik vegetatif maupun teknik generatif.

\section{Ucapan Terima Kasih}

Tim Peneliti menyampaikan terima kasih atas penyediaan dana Pengabdian Kepada Masyarakat melalui PNBP Universitas Mataram tahun 2018.

\section{DAFTAR PUSTAKA}

Al-Azharia, J.S. 1981. Traditional Water Purification in Tropical Developing Countries: Existing Methods and Potential Application. Eschborn, GTZ, 1981.

Daryanto, A. 2005. Analisis Kebijakan Pemerintah di Bidang Energi: Penanaman Jarak Pagar sebagai Solusi Alternatif Pengadaan Sumberdaya Energi Terbarukan Seminar Nasional "Pengembangan Jarak Pagar (Jatropha curcas Linn.) untuk Biodiesel dan Minyak Bakar". Pusat Penelitian Surfaktan dan Bioenergi-LPPM IPB, Kampus IPB Gunung Gede, Bogor. 22 Desember 2005.

Foidl N., Makkar H., Becker K. 2001. The miracle Tree The Multiple uses of Moringa. Wagening. Netherlands. p: 45-76.

Haryadi, Nur Kholis. 2011. Kelor Herbal Multikhasiat. Solo: Delta Media.

Hidayat, S., 2003, Efektifitas Bioflokulan Biji Moringa Oleifera Dalam Proses Pengolahan Limbah Cair Industri Pulp Dan Kertas, http:// digilib. Ibitb.ac.ai/ go.php

Hidayat, S., 2006, Pemberdayaan Masyarakat Bantaran Sungai Lematang Dalam Menurunkan Kekeruhan Air Dengan Biji Kelor (Moringa oleifera, Lamk) Sebagai Upaya Pengembangan Proses Penjernihan Air. Disertasi, Program Pasca Sarjana, Universitas Negeri Malang

Kadiman, K. 2006. Pengembangan Teknologi Bioenergi di Indonesia. Seminar Nasional Pengembangan dan Pemanfaatan Jarak Pagar Sebagai Bio-Energi di Indonesia. Hotel Shangri-La, Jakarta 25 Februari 2006.

Krisnadi, A Dudi. 2013. e-Book Kelor Super Nutrisi. Blora: KELORINA.COM.

Manurung, R. 2006. Minyak Jarak Pagar Murni (Pure Jatropha Oil) Bahan Baku Pengganti Bahan Bakar Minyak. Seminar Nasional Pengembangan dan Pemanfaatan Jarak Pagar Sebagai Bio-Energi di Indonesia. Hotel Shangri-La, Jakarta 25 Februari 2006.

Misra, .K. and H. R. Jaiswal. 1993. Effect size of polythene bags and potting mixure on the survival and growth of Silver Oak (Grevillia robusta Parker) seedlings. Indian Forester 119: 940-943. 
Ofor, Marian O., Nwufo, Martin I. 2011. The Search for Alternative Energy Source Jatropha and Moringa Seed for Bioful Production. Journal of Agriculture and Social. Vol 11 (2):77-82.

Saad, S. 2006. Strategi Pemberdayaan Masyarakat Pesisir Melalui Pengembangan Jarak Pagar. Seminar Nasional Pengembangan dan Pemanfaatan Jarak Pagar Sebagai Bio-Energi di Indonesia. Hotel Shangri-La, Jakarta 25 Februari 2006.

Siregar, H., Harianto, Nur AA. 2005. Analisis Usahatani dan Skala Usaha Tanaman Jarak. Seminar Nasional Pengembangan Jarak Pagar untuk Biodiesel dan Minyak Bakar. Diselenggarakan Pusat Penelitian Surfaktan dan Bioenergi, Institut Pertanian Bogor. 22 Desember 2005. 